\title{
MONITORING OF CYPRIPEDIUM CALCEOLUS (ORCHIDACEAE) IN THE ADAMELLO-BRENTA NATURAL PARK (ITALY)
}

\author{
Giorgio Perazza ${ }^{1,2}$, Michela Decarli ${ }^{3}$ \\ ${ }^{1}$ Italian Research Group on the Orchids of Europe - GIROS, Italy \\ ${ }^{2}$ Rovereto Civic Museum Foundation, Italy \\ ${ }^{3}$ Rovereto Civic Museum Society, Italy \\ e-mail:perazzagiorgio@fondazionemcr.it,michela.decarli47@gmail.com
}

Received: 10.03.2020. Revised: 26.07.2020. Accepted: 05.08.2020.

\begin{abstract}
The study reports data from a long-term monitoring (2007-2020) of a Cypripedium calceolus population (Orchidaceae) in the Adamello-Brenta Natural Park (Trentino, North Italy). In the first four years, there was a gradual increase in the number of flowering stems. In 2010, a forest cut was performed and branches were left in place for three years. Number of orchid individuals decreased rapidly just after the cut, while after the removal of the branches in 2013 a recovery began. The proportion of stems with two flowers varied between $8.8 \%$ and $17.6 \%$. Reproductive success was studied only in the first three years, varying between 5.2\% and 19.7\%. Several plants did not bloom because they were grazed by wild ungulates. As we observed that hikers and tourists collected some plants, we also recommend the surveillance of Cypripedium calceolus population during flowering period. Despite these multiple impacts, the studied population look to be viable. However, more attention should be implemented to future forest interventions.
\end{abstract}

Key words: endangered species, Lady's slipper, fruit set, Protected Area, population dynamics, Trentino

\section{Introduction}

The Orchidaceae family draws a lot of interest among floriculturists, but also among amateurs, researchers and naturalists (e.g. GIROS, 2016). Due to their particular ecological needs, first of all the specific relationships with the pollinators (Antonelli et al., 2009; Claessens \& Kleynen, 2011), the mycorrhizal symbiosis and the very low seed germination (Rasmussen, 1995; Kull et al., 2016), almost everywhere orchids are considered to be valid biological indicators (European Commission, 2007; Biondi et al., 2012; Kull et al., 2016). Worldwide, many species are rare and/ or under threat of extinction mainly due to habitat transformation (e.g. Khapugin et al., 2017; Djordjević \& Tsiftsis, 2020).

Cypripedium calceolus L. (Lady's slipper) is one of the most striking orchids of Eurasia. It is often threatened within its geographical range, which is distributed from Scandinavia to Northeast Spain, central Italy and through central Europe and Siberia it reaches Japan (Kull, 1999; Terschuren, 1999; Antonelli et al., 2009; Rankou \& Bilz, 2014; Kull et al., 2016; Khapugin et al., 2017; Kolanowska \& Jakubska-Busse, 2020). It is a long-living clonal and rhizomatous geophyte species (Kull, 1999; Shefferson et al., 2005). Cypripedium calceolus prefers calcareous substrates such as limestone, whereas the known soil $\mathrm{pH}$ range is 4.50-8.26 (Djordjević \& Tsiftsis, 2020). The Natura 2000 habitats interpretation manual (European Commission, 2007) reports it as a characteristic species of Scandinavia in wooded meadows (code 6530*) and grassy forests with Picea abies (L.) H.Karst. (code 9050) (Biondi et al., 2012). In the Brenta Massif, and more extensively in Trentino, it also grows in other habitats such as margins of scree and landslides, bushes and Mountain pine (Pinus mugo Turra) forests, Scots pine (Pinus sylvestris L.) forests, clearings in beech (Fagus sylvatica L.) woods and spruce (Picea abies) forests (limestone only) (Perazza \& Lorenz, 2013). The species is legally protected at a national level in most countries. It is included under Appendix II of CITES, Appendix I of the Bern Convention and Annex II of the Habitats Directive 92/43/ EEC. The IUCN Red List of Threatened Species assessed Cypripedium calceolus as Least Concern (LC) taxon (Rankou \& Bilz, 2014).

In Italy, Cypripedium calceolus is a rather rare and protected species. Rankou \& Bilz (2014) reported 199 localities for Italy, despite being completely absent in several regions (GIROS, 2016; Pignatti, 2017). The species is evaluated as Least Concern (LC) in the Red List of the Italian Flora (Rossi et al., 2013). It occurs in the limestone-dolomitic alpine areas of north-eastern Italy (Perazza \& Lorenz, 2013). In Trentino (Autonomous Province of Trento, North Italy) it is quite widespread (Perazza \& Decarli Perazza, 2002, 2005; Prosser et al., 2019), but it is locally declining, being evaluated as LR (Lower Risk) in the Red List of the Trentino Flora (Prosser et al., 2019).

Some of the largest populations of $C$. calceolus in Trentino are known in the Adamello-Brenta Nat- 
ural Park (PNAB). It is distributed in the different valleys of the Brenta Dolomites (Perazza \& Decarli Perazza, 2002, 2005; Festi \& Prosser, 2008). To improve the knowledge and check the performances of these populations, the PNAB has entrusted field research for the annual monitoring of a sample population to the Civic Museum of Rovereto (MCR).

The aims of the present study were i) to determine the population status of the species in terms of number of individuals, number of single-flower/ two-flower stems, and reproductive success; ii) to determine annual population dynamics, and iii) to provide useful information for management and conservation purposes.

\section{Study area}

The PNAB is located in Western Trentino (Fig. 1). Its area is divided into two geologically distinct districts. The first one is the silicate massif of the Adamello-Presanella (western part), and the second one is the Brenta Dolomites, for the most part carbonate (eastern part). The study area is located in the eastern sector, in Val Brenta near the former Malga Brenta Bassa $\left(46.1986943^{\circ} \mathrm{N}\right.$, $\left.10.8236909^{\circ} \mathrm{E}\right)$, at an altitude of $1261 \mathrm{~m}$ a.s.1. (CT-PAT). We selected this location for monitoring due to a rich population of Cypripedium calceolus (Perazza, 1992; Perazza \& Decarli Perazza, 2002; Bonazza et al., 2004; Rivalta, unpublished). Here, the species was well established, and located in easily accessible sites but not too disturbed by anthropogenic activities and tourists.

In 2006, we preliminarily explored a long stretch of the valley along the right bank of the Sarca of Brenta stream. In 2007-2020, the study area was restricted to a part explored in 2006. The boundaries were defined as a strip in the valley between the right bank of the stream and the gravel road, from the bridge by Malga Brenta Bassa to a fallen boulder where the valley floor narrows (1288 $\mathrm{m}$ a.s.1.). Its length is about $920 \mathrm{~m}$. The overall differences in altitudes are about $27 \mathrm{~m}$.

\section{Habitat description}

The Sarca of Brenta stream flows entirely on limestone-dolomitic ground. The prevailing vegetation is a mixed mountain forest, in which Fagus sylvatica was dominant until the middle - late XX century (Dalla Fior, 1949). In the following decades, forestry favoured Picea abies at the expense of Fagus sylvatica. Today the valley shows ecotonal characteristics, due to both an- thropogenic (pasture, reforestation) and natural (floods) factors. It is characterised by a mosaic of diversified habitats with prevalence of conifers or broad-leaved trees, with more or less open and / or bushy clearings. In general, the habitat of Cypripedium calceolus is similar to its habitats recorded in other areas of Europe (e.g. Kull, 1998; Terschuren, 1999; Baumann, 2005; Antonelli et al., 2009; Khapugin et al., 2017).

In the northwest part of the study area there is a certain degree of disturbance where Cypripedium calceolus is damaged by animals and humans. The meadow near the Malga Brenta Bassa is grazed, even if only in two very short seasonal phases as an intermediate stage in the herds transhumance for about a week in early June (when Cypripedium calceolus is still in bud), and in the reverse path backwards in September. In addition, the summer pasture was used by people and frequently visited by groups of hikers and tourists. Here the forest is dominated by the spruce (Picea abies) mostly subadult trees, growing on shallow soils, sometimes in dense and impenetrable formations. In many places the soil is in a dense shade and is covered with a layer of mosses. In the southeast part of the area, subject to less anthropic impact, the soil is more alluvial and sometimes affected by floods. Under these conditions, thickets prevail with young or very young Picea abies trees with Pinus sylvestris, P. mugo and Salix spp. In open habitats along the streambed, rubble and gravel form islands of sparse shrubby and grassy vegetation, periodically rearranged by the stream floods. The sparse vegetation near the shore allows a good light availability. Here, the occasional floods produce free microspaces on the soil, not yet covered by other herbs. The ground offers many points with interrupted turf, where the seeds can germinate.

\section{Data collection}

The purpose of the present study was to verify the presence/absence and the population trends of Cypripedium calceolus. In addition, the single stems (flowering and non-flowering) of Cypripedium calceolus were counted. We studied the whole area, counting the stems and recording their abundance and locations. The observations were noted every few square metres. The counting of the flowers took place in mid-June (2007-2020), i.e. during the period of full flowering. At the same time, observations of the fruiting period were conducted in September (from 2006 to 2008) when the capsules were well developed. 


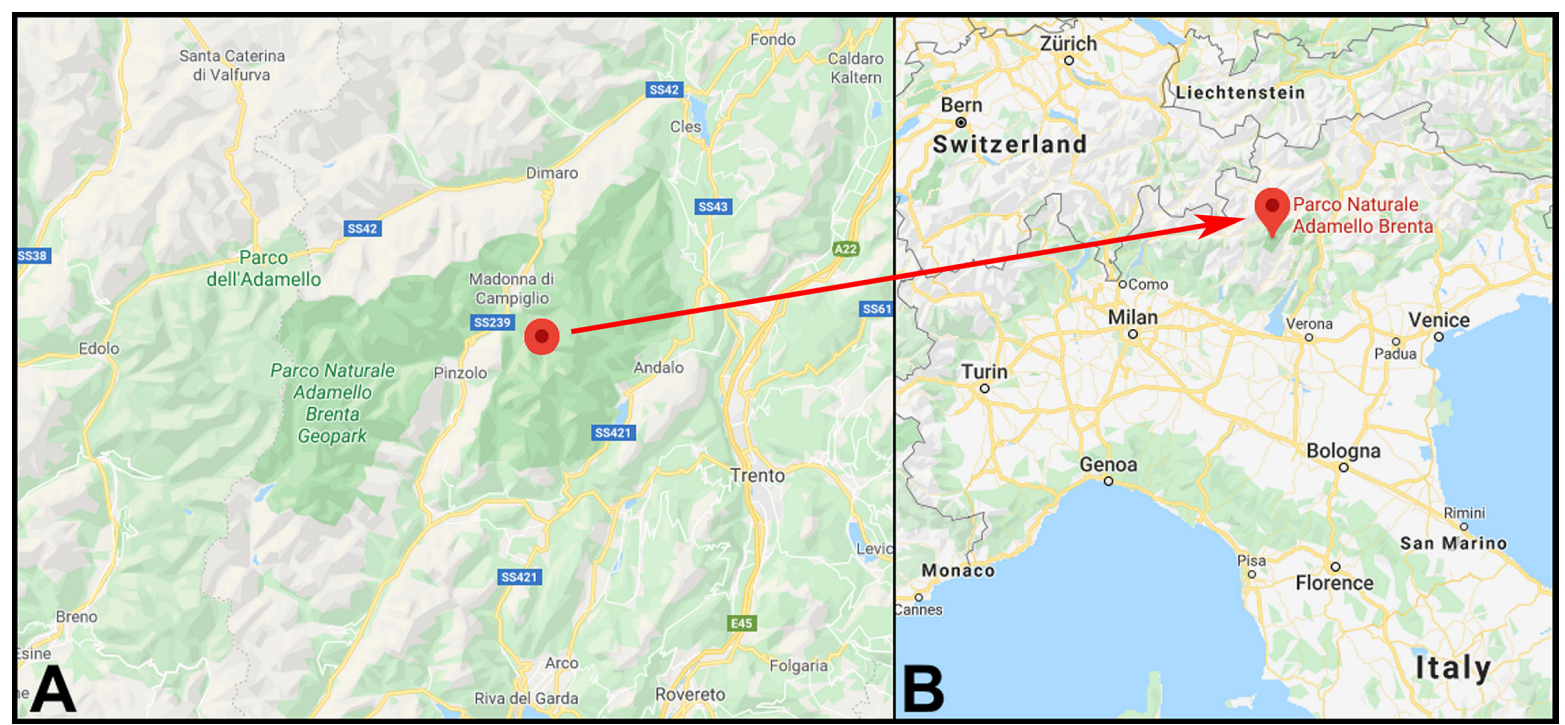

Fig. 1. The location of the Val Brenta area in the Adamello-Brenta Natural Park, Italy (A), and in Trentino, North Italy (B). Map was used from Google Map with modifications.

Reproductive success was calculated on the basis of the number of flowers and the number of capsules produced. The calculation was used on the basis of the total number of $C$. calceolus flowers found in June (Fig. 2).

\section{Data analysis}

The collected data were processed in the labour conditions and filled according to the project «Cartography of the Orchids of Trentino» (Perazza 1992; Perazza \& Decarli Perazza, 2005), georeferenced (GIS) on the Technical Map 1:10.000 of the Autonomous Province of Trento (CT-PAT) according to «Floristic Cartography of Trentino» (Prosser \& Festi, 1993), added in the database of the MCR and subsequently transferred to the PNAB.

\section{Results}

In the study area, the numerical trend of the Cypripedium calceolus population is illustrated in Fig. 3. In 2007 and 2008, we observed a progressive numerical increase in number of stems. In 2009, there was a further increase in flowering stems, but partially offset by a decrease in non-flowering ones. In 2010, we noted a further increase in flowering stems. But we were unable to detect all small-size, non-flowering stems as they were often submerged by fallen branches and trees. In fact, we found the area cluttered with plants and Picea abies branches cut for forestry reasons. The mass of branches and waste was not immediately removed. It remained there until autumn 2012, i.e. over three vegetative seasons, with negative effects on the Cypripedium calceolus population, the status of which continued decreasing until 2013. Its population recovery began in 2014 and continues till today with a slow, progressive increase. In 2017, there was a sudden increase in non-flowering stems, immediately reduced from 2018 probably due to an overflow of gravel carried by the stream covered seedlings and juveniles.

Separate counting of single-flower/twoflower stems was detected only during six years (Table 1). The proportions fluctuated from year to year. The average proportion of two-flower stems was $12.4 \%(\mathrm{SD}=2.98)$.

The reproductive success rate (Table 2) was measured only in 2006-2008. In the summer, the flowering stems were recognisable by the presence of well-developed capsules or, if they had not been fertilised, by the dried up remains of the flower pedicels. Despite thorough research, each year in September, the number of re-found stems was lower than it was recorded in June. Some of them had perhaps escaped observation. However, others had certainly disappeared. The missing ones were either grazed by ungulates or collected, despite protection. The sharp decrease in their number was surprising. It is impossible to investigate the precise causes because this would entail the constant presence of personnel on the study site.

In September 2006, we found 85 healthy capsules produced out of 432 flowers (fruit set $=19.7 \%$ ). In September 2007, the 328 flowers registered in June produced only 17 capsules (fruit set $=5.2 \%$ ). In September 2008, the 512 flowers registered in June produced 49 capsules (fruit set $=9.6 \%$ ). 


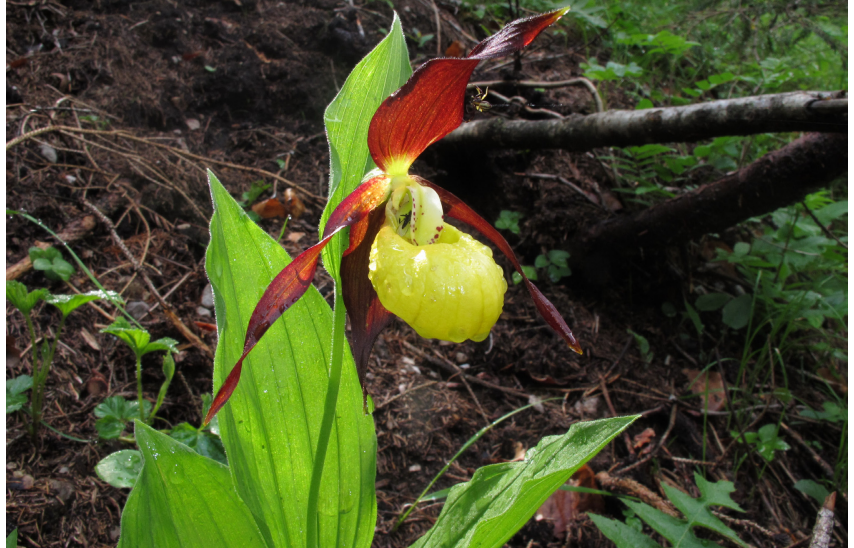

Fig. 2. Cypripedium calceolus L., flower, Malga Brenta Bassa.

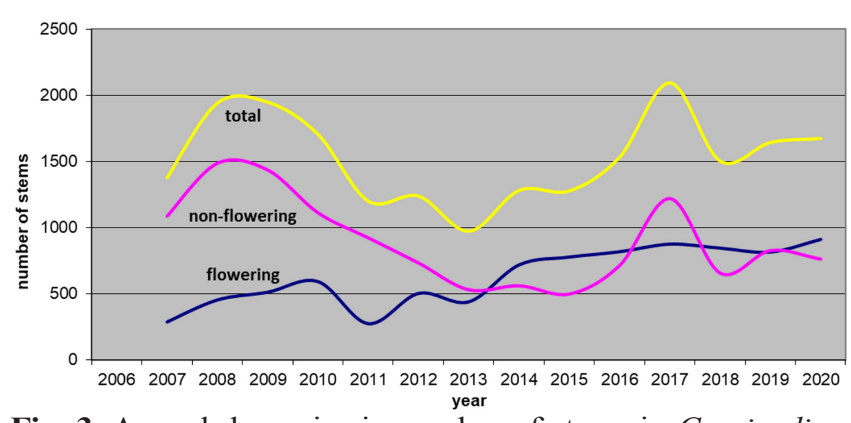

Fig. 3. Annual dynamics in number of stems in Cypripedium calceolus population in the Adamello-Brenta Natural Park (Italy). Designations: blue line - flowering stems; purple line - nonflowering stems (including mature vegetative, immature and juvenile); yellow line - total number of stems.

Table 1. Six-year counting of single-flower and two-flower stems in Cypripedium calceolus population in the AdamelloBrenta Natural Park (Italy)

\begin{tabular}{|c|c|c|c|c|c|}
\hline Year & $\begin{array}{c}\text { Number of } \\
\text { flowering stems }\end{array}$ & $\begin{array}{c}\text { Number of } \\
\text { 1-flower stems }\end{array}$ & $\begin{array}{c}\text { Proportion of the total } \\
\text { number of stems, } \%\end{array}$ & $\begin{array}{c}\text { Number of } \\
\text { 2-flower stems }\end{array}$ & $\begin{array}{c}\text { Proportion of the total } \\
\text { number of stems, \% }\end{array}$ \\
\hline 2007 & 290 & 252 & 86.9 & 38 & 13.1 \\
\hline 2008 & 456 & 400 & 87.7 & 56 & 12.3 \\
\hline 2009 & 514 & 460 & 89.5 & 54 & 10.5 \\
\hline 2010 & 594 & 523 & 88.0 & 71 & 12.0 \\
\hline 2012 & 505 & 416 & 82.4 & 89 & 17.6 \\
\hline 2013 & 442 & 403 & 91.2 & 39 & 8.8 \\
\hline
\end{tabular}

Table 2. Numbers of flowering stems, flowers, capsules and fruit set of the Cypripedium calceolus population over 2006-2008

\begin{tabular}{|c|c|c|c|c|}
\hline Year & Flowering stems & Flowers & Capsules & Fruit set, $\%$ \\
\hline 2006 & 403 & 432 & 85 & 19.7 \\
\hline 2007 & 290 & 328 & 17 & 5.2 \\
\hline 2008 & 456 & 512 & 49 & 9.6 \\
\hline
\end{tabular}

Note: Fruit set was calculated as a total number of capsules from the total number of flowers observed in June.

\section{Discussion}

Due to different habitat types scattered in the study area where Cypripedium calceolus grows, there are considerable differences in the quantity, age and development of plants and in their possibility of seed germination and seedling development (Kull, 1998; Khapugin et al., 2017). We assumed that in the northwest part of the study area, forest canopy shading limits pollination, while the seedling recruitment is hampered by the moss layer that is similar to the findings of Kull (1998). The same author also underlined the presence of adult plants in a population with several clones propagating vegetatively (Kull, 1998). We also confirmed a similar situation in the study area, where the nonflowering stems had often the size of mature vegetative individuals having 3-4 large leaves, and the presence of a few seedlings.

Another situation was in the southeast part characterised by the sparse vegetation and higher soil radiation. According to Kull (1999), it should be emphasised that under full illumination the Cypripedium calceolus individuals are smaller in size; the majority of the stems are single, not arranged in clumps, and there is a considerable proportion of seedlings and well-developed juvenile and immature plants (with 2-3 leaves). Better illumination favours growth, fertilisation and fruiting of the orchid without costs (Jacquemyn et al., 2010). The small young Picea abies trees offer protection of plants against grazing and trampling. This part looks to be the most favourable for Cypripedium calceolus, as well as the narrow strip on the stream banks.

We wonder about the possible reasons for the observed numerous fluctuations. A marked decrease began in 2010 (Fig. 3), following forestry actions. However, other unknown causes played a role because the decrease occurred everywhere in the study area, both in the part subjected to cuts and in the undisturbed one. In 2012, a well-marked increase in number of flowering stems occurred, while, on the contrary, the non-flowering stems further decreased. It is difficult to understand the cause of this fluctuation. In autumn (two years after forest cutting), the study area was finally cleared 
of fallen trees and branches through chipping of the material on the site. Therefore, space and light were returned to the plants of Cypripedium calceolus that had been buried under the woody material. The recovery was not immediate. So, in 2013, there was a further decrease in number of stems and, only in 2014-2020, a new increase in number of the flowering stems occurred. This increase was likely related to the mentioned cutting and cleaning of the wood. These facts could favour the flowering initiating of previously non-flowering individuals, long-weakened by the light scarcity. It was obviously comfortable for Cypripedium calceolus that this increase remained constant over the years until 2020. The peak in number of non-flowering individuals in 2017 , followed by the sharp decrease just a year later, was also without an apparent explanation. Sometimes, the observed temporary numerical reduction in number of plants might be due to stress conditions leading to buds' dormancy (Kull, 1999; Shefferson et al., 2005). But we did not investigate this in the present study. In some locations, we found a little renewal caused perhaps by the lack of free spaces where the seeds can germinate and the seedlings can have the chance to compete with other species (Kull, 1998).

An appropriate management should avoid habitat loss and population fragmentation leading to a higher risk of genetic erosion (Minasiewicz et al., 2018), as it is reported for the Apennino's Italian sites, located at the edge of its range (Terschuren, 1999, Rossi et al., 2001). For this purpose, periodic forest thinning and clearing should be sufficient at some strategic points. We still have no evidence of the potential risk from ongoing climate changes (Kolanowska \& Jakubska-Busse, 2020).

The proportion between non-flowering and flowering stems (cf. Khapugin et al., 2017) was also subject to fluctuations (Fig. 3). In 2008, the number of non-flowering stems was about three times lower than the flowering ones. Then the ratio decreased until it reversed and then rose alternately. Such fluctuations were observed mainly in the gravelly sites where the floods sometimes localised the seedlings under layers of debris.

The fruit set fluctuated over the years and differed between the two parts of the study area. The deceptive flowers of Cypripedium calceolus are a trap from which pollinators come out with difficulty. And once a pollinator becomes free, it usually moves further away before falling back into the trap held by another flower. Therefore cross-pollination between distant individuals is favoured (Kull,
1998; Kull, 1999; Khapugin et al., 2017). We also found earlier the same behaviour in Val Brenta. In line with previous observations (Perazza \& Decarli Perazza, 2002; Rivalta, unpublished), in two-flower specimens, a few times both flowers are fertilised. And there were no significant differences in the pollination between the lower and upper flower. The proportion of capsules produced per clone is clearly lower than for separate individuals.

On other locations of the Val Brenta, previous observations found that the fruit set was about 13\% (A. Bonazza in Perazza \& Decarli Perazza, 2002) or ranged between 5\% and 14\% during 2000-2002 (Bonazza et al., 2004). In 2006-2008, the average value of the fruit set of our observations (i.e. 1272 flowers, 151 capsules) was $11.9 \%$, comparable with the mean fruits set of $10.5 \%$ obtained over 11 years in Estonia (Kull, 1998). But our results are rather low compared to other populations in Trentino (in average, it was $22.63 \%$ according to Perazza \& Decarli Perazza, 2002) and considerably lower than $36.7 \%$ observed during six years in the Republic of Mordovia (Khapugin et al., 2017). Such low values of the fruit set obtained during 2006-2008 in Val Brenta were caused perhaps by unfavourable climatic conditions during flowering period, which limited the activity of pollinators. But another assumed reason is also a progressive forest darkening that can have negative effects on flower attractiveness to pollinators (Kull, 1999; Antonelli et al., 2009; Claessens \& Kleynen, 2011) and for fruiting cost (Jacquemyn et al., 2010). Despite the low germination rate (Kull et al., 2016), the fruit set guarantees sufficient dissemination to maintain the orchid population, as it is evidenced by the presence of numerous young individuals.

\section{Conclusions}

In Val Brenta, the Cypripedium calceolus population is viable and it seems to be in good condition despite some habitat disturbance. The population trend showed annual fluctuations without clear drivers, except for the increase in the number of flowering stems starting from the third study year following the forest clearing in 2010. In the northwest part of the study area, suffering plants or groups of plants are in regression status probably caused by an increased shading. Locally, targeted cuts of some trees and thinning of dense shrubs can improve illumination on the ground and therefore promote flowering and pollination of C. calceolus individuals. The fruit set appeared sufficient to maintain the orchid population. 
The management seems adequate and extensible to the whole Brenta Group. However, stems often cut at the apex were observed with relatively high frequency. Probably, in the pre-flowering period, these stems were grazed by wild ungulates, especially $\mathrm{Cer}$ vus elaphus Linnaeus, 1758. The disappearance of flowering stems in September suggests that plants are collected by hikers and tourists, although this species is protected and the locality is situated in a Natural Park. So a stricter surveillance would be advisable at least during the flowering period.

\section{Acknowledgements}

We thank the Management of the Rovereto Civic Museum Foundation for logistical help, and the Management of the Adamello-Brenta Natural Park for the authorisation to publish the data (Prot. No. $5545 / 8.1$ ). We thank to all who collaborated in the censuses, whether they are Park operators such as Marco Merli, Pino Oss Cazzador, Giuliana Pincelli, or nature enthusiasts such as Andrea Battilana (Milan, Italy), Carlo Caliari (Rovereto, Italy), Pierernesto Righi (Strembo, Italy) and Alberto Rivalta (Bagnacavallo, Italy). We especially thank also A. Rivalta for having made the results of his 25-year observations in Val Brenta available for us, to Mauro Biagioli (Prato, Italy) for assistance, Lorenzo Marini and Costanza Geppert (both Padua Univerity, Italy) for the English revision.

\section{References}

Antonelli A., Dahlberg C.J., Carlgren K.H.I., Appelqvist T. 2009. Pollination of the Lady's slipper orchid (Cypripedium calceolus) in Scandinavia - taxonomic and conservational aspects. Nordic Journal of Botany 27(4): 266-273. DOI: 10.1111/j.1756-1051.2009.00263.x

Baumann H. 2005. Cypripedium calceolus L. In: Arbeitskreise Heimische Orchideen (Hrsg.): Die Orchideen Deutschlands. Uhlstädt-Kirchhasel: Hoehl-Druck. P. 279-281.

Biondi E., Burrascano S., Casavecchia S., Copiz R., Del Vico E., Galdenzi D., Gigante D., Lasen C., Spampinato G., Venanzoni R., Zivkovic L., Blasi C. 2012. Diagnosis and syntaxonomic interpretation of Annex I Habitats (Dir. 92/43/EEC) in Italy at the alliance level. Plant Sociology 49(1): 5-37. DOI: 10.7338/pls2012491/01

Bonazza A., Caniglia G., Moraldo B., Rossi W. 2004. Preliminary Data on the Ecology of Cypripedium calceolus L. in a few Populations from Trentino Alto Adige. Journal Europäischer Orchideen 36(2): 431-454.

Claessens J., Kleynen J. 2011. The flower of the European orchid. Form and function. Voerendal/Stein: SchrijenLippertz. 440 p.

Dalla Fior G. 1949. Vegetazione e flora. In: E. Castiglioni (Ed.): Dolomiti di Brenta. Milano: CAI-TCI. P. 30-32.

Djordjević V., Tsiftsis S. 2020. The Role of Ecological Factors in Distribution and Abundance of Terrestrial Orchids. In: J.M. Merillon, H. Kodja (Eds.): Orchids Phytochemistry, Biology and Horticulture. Cham: Springer. P. 1-71.
European Commission. 2007. Natura 2000. Interpretation Manual of European Union Habitats EUR27. DG Environment: Nature and biodiversity.

Festi F., Prosser F. 2008. Flora del Parco Naturale Adamello Brenta. Documenti del Parco no. 17. Rovereto: Osiride. 608 p.

GIROS. 2016. Orchidee d'Italia. Guida alle orchidee spontanee. $2^{\text {nd }}$ ed. Cornaredo: Il Castello. 368 p.

Jacquemyn H., Rein Brys R., Jongejans E. 2010. Size-dependent flowering and costs of reproduction affect population dynamics in a tuberous perennial woodland orchid. Journal of Ecology 98(5): 1204-1215. DOI: $10.1111 / \mathrm{j} .1365-2745.2010 .01697 . \mathrm{x}$

Khapugin A.A., Chugunov G.G., Vargot E.V. 2017. Cypripedium calceolus (Orchidaceae) in Central Russia: a case study for its populations in two Protected Areas in the Republic of Mordovia (Russia). Lankesteriana 17(3): P. 403-417. DOI: 10.15517/ lank.v17i3.31577

Kolanowska M., Jakubska-Busse A. 2020. Is the lady'sslipper orchid (Cypripedium calceolus) likely to shortly become extinct in Europe? - Insights based on ecological niche modelling. PLoS ONE 15(1): e0228420. DOI: 10.1371/journal.pone. 0228420

Kull T. 1998. Fruit-set and recruitment in populations of Cypripedium calceolus L. in Estonia. Botanical Journal of the Linnean Society 126(1-2): 27-38. DOI: $10.1111 / \mathrm{j} .1095-8339.1998 . t b 02513 . x$

Kull T. 1999. Cypripedium calceolus L. Journal of Ecology 87(5): 913-924. DOI: 10.1046/j.13652745.1999.00407.x

Kull T., Selgis U., Peciña M.V., Metsare M., Ilves A., Tali K., Sepp K., Kull K., Shefferson R.P. 2016. Factors influencing IUCN threat levels to orchids across Europe on the basis of national red lists. Ecology and Evolution 6(17): 6245-6265. DOI: 10.1002/ece3.2363

Minasiewicz J., Znaniecka J. M., Górniak M., Kawiński A. 2018. Spatial genetic structure of an endangered orchid Cypripedium calceolus (Orchidaceae) at a regional scale: limited gene flow in a fragmented landscape. Conservation Genetics 19(6): 14491460. DOI: $10.1007 / \mathrm{s} 10592-018-1113-4$

Perazza G. 1992. Orchidee spontanee in Trentino-Alto Adige. Riconoscimento e diffusione. Fotoatlante con chiavi analitiche e carte di distribuzione per la provincia di Trento. Calliano: Manfrini. 184 p.

Perazza G., Decarli Perazza M. 2002. Cartografia Orchidee Tridentine (COT): Cypripedium calceolus L. e Liparis loeselii (L.) Rich., specie citate nella Direttiva Habitat della CEE. Atti della Accademia roveretana degli Agiati, fasc. B 8(2): 129-210.

Perazza G., Decarli Perazza M. 2005. Cartografia Orchidee Tridentine (COT): mappatura delle orchidee spontanee in provincia di Trento (Italia Settentrionale), aggiornamento generale. Annali del Museo Civico di Rovereto 20(2004): 153-339.

Perazza G., Lorenz R. 2013. Le orchidee dell'Italia nordorientale, atlante corologico e guida al riconoscimento. Rovereto: Osiride. 448 p. 
Pignatti S. 2017. Flora d'Italia. $2^{\text {nd }}$ ed. Vol. 1. Bologna: Edagricole-New Business Media. 1064 p.

Prosser F., Bertolli A., Festi F., Perazza G. 2019. Flora del Trentino. Rovereto: Osiride. 1214 p.

Prosser F., Festi F. 1993. Cartografia floristica in Trentino. Informatore Botanico Italiano 24: 23-31.

Rasmussen H.N. 1995. Terrestrial orchids from seed to mycotrophic plant. Cambridge: Cambridge University Press. 444 p.

Rankou H., Bilz M. 2014. Cypripedium calceolus. In: The IUCN Red List of Threatened Species 2014: e.T162021A43316125. Available from https://dx.doi.org/10.2305/IUCN.UK.20141.RLTS.T162021A43316125.en

Rossi W., Mosco M.C., Bullini L. 2001. Genetic erosion in Italian populations of threatened orchids: Cypripedium calceolus, Orchis palustris and Dac- tylorhiza incarnata. In: First International Orchid Conservation Congress. Perth. P. 60.

Rossi G., Montagnani C., Gargano D., Peruzzi L., Abeli T., Ravera S., Cogoni A., Fenu G., Magrini S., Gennai M., Foggi B., Wagensommer R.P., Venturella G., Blasi C., Raimondo F.M., Orsenigo S. (Eds.). 2013. Lista Rossa della Flora Italiana. 1. Policy Species e altre specie minacciate. [Roma]: Comitato Italiano IUCN e Ministero dell'Ambiente e della Tutela del Territorio e del Mare. 58 p.

Shefferson R.P., Kull T., Tali K. 2005. Adult whole-plant dormancy induced by stress in long-lived orchids. Ecology 86(11): 3099-3104. DOI: 10.1890/05-0586

Terschuren J. 1999. Action plan for Cypripedium calceolus in Europe. In: Nature and Environment (No. 100-104). Strasbourg: Council of Europe Publishing. 62 p.

\title{
МОНИТОРИНГ СУРRIPEDIUM CALCEOLUS (ORCHIDACEAE) В ПРИРОДНОМ ПАРКЕ «АДАМЕЛЛО-БРЕНТА» (ИТАЛИЯ)
}

\author{
Дж. Перацца ${ }^{1,2}$, М. Декарли ${ }^{3}$ \\ ${ }^{1}$ Итальянская исследовательская группа по орхидным Европы, Италия \\ ${ }^{2}$ Фонд городского музея Роверето, Италия \\ ${ }^{3}$ Общество городского музея Роверето, Италия \\ e-mail:perazzagiorgio@fondazionemcr.it,michela.decarli47@gmail.com
}

\begin{abstract}
Настоящее исследование представляет данные долгосрочного (2007-2020) мониторинга популяции Cypripedium calceolus (Orchidaceae) в природном парке «Адамелло-Брента» (Трентино, Северная Италия). В первые четыре года было отмечено постепенное увеличение числа генеративных особей в популяции. В 2010 г. в этом местообитании была проведена рубка леса, в результате которой ветви оставлены на три года. Число особей орхидеи быстро уменьшилось после рубки, но после удаления ветвей в 2013 г. наблюдалось восстановления количества особей в популяции. Доля генеративных особей с двумя цветками варьировала между 8.8\% и 17.6\%. Репродуктивный успех (плодообразование) был изучен только в первые три года исследования, варьируя от 5.2\% до 19.7\%. Несколько растений не цвели, так как побеги были объедены копытными животными. Так как нами отмечено, что путешественники и туристы собирали некоторые растения в букеты, мы рекомендуем проведение мониторинга популяции Cypripedium calceolus в течение периода цветения орхидеи. Несмотря на многочисленные факторы воздействия, изученная популяция производит впечатление жизнеспособной. Тем не менее, должно быть уделено большее внимание будущим лесохозяйственным мероприятиям на территории исследования.
\end{abstract}

Ключевые слова: венерин башмачок настоящий, динамика популяции, исчезающий вид, особо охраняемая природная территория, плодообразование, Трентино 